\title{
Some blood plasma constituents correlate with human cataract
}

\author{
C A Donnelly, J Seth, R M Clayton, C I Phillips, J Cuthbert, R J Prescott
}

Department of

Mathematics and Statistics, University of Edinburgh

C A Donnelly

Department of Clinical Biochemistry, Royal Infirmary Edinburgh NHS Trust and University of Edinburgh J Seth

ICAPB Division of Biology, University of Edinburgh

R M Clayton

J Cuthbert

Ophthalmology Unit, Department of Surgery, University of Edinburgh and Princess Alexandra Eye Pavilion, Royal Infirmary, Edinburgh C I Phillips

Medical Statistics Unit, University of Edinburgh

R J Prescott

Correspondence to: Dr C A Donnelly, Department of Mathematics and Statistics, University of Edinburgh, James Cler Maxwell Building, the King's Buildings, Mayfield Road, Edinburgh EH9 3JZ.

Accepted for publication 18 July 1995

\begin{abstract}
Aims-To look for differences between matched pairs of patients and controls in concentrations of various plasma constituents which might indicate dysfunctions associated with cataract.

Method-One thousand patients were taken from the cataract waiting list of a specialist eye hospital. For each patient a matched control of the same sex and halfdecade of age but without cataract was taken from the patient list of the family doctor of the patient; the control was the next alphabetically after the patient on the doctor's list. The patients and controls were visited in their homes by a team of nurses who performed venepunctures and collected information for a questionnaire. Eye examinations were performed by a team of ophthalmologists.
\end{abstract}

Results-Significant differences were found between the cataract and control groups in 10 of the 18 examined plasma constituents. A constellation of three bilirubin, alkaline phosphatase, and $\gamma$ glutamyl transpeptidase - was significantly higher in the cataract group, suggesting subclinical liver dysfunction as a risk factor. Steroid treatment and diabetes increased cataract risk. Endogenous basal plasma cortisol levels were raised in the cataract group, irrespective of steroid use and diabetic status. Alkaline phosphatase, calcium, glucose, and sodium were all raised in the cataract group. Given the raised total protein and albumin also found in the cataract group, the lower albumin/(total protein-albumin) ratio (an approximation for albumin/ globulin ratio) may imply an increase in globulin, suggestive of possible (chronic) infection. Total cholesterol was lower in the cataract group.

Conclusion-Human cataract in older age groups seems to be due to an accumulation of risk factors, even if individual mean concentrations are well within normal limits but, of course, differing significantly from the corresponding means in the control population.

(Br f Ophthalmol 1995; 79: 1036-1041)

It is now generally agreed that a number of risk factors are associated with the development of age-related cataract. While a few, such as elevated levels of plasma glucose ${ }^{1}$ and diabetes, ${ }^{2}$ have long been known, significantly changed concentrations in a number of other plasma constituents have also been reported as associated with an increased relative risk of cataract: the first Edinburgh study of a wide range of such variables was reported in several publications ${ }^{3-8}$; more recent reports were in $1989^{910}$ and $1991 .^{11}$

In the first Edinburgh based study, our group found significantly raised levels of bilirubin, creatinine, and glucose in patients compared with controls, but significantly lowered levels of total protein, phosphate, and cholesterol. 57

Schoenfeld et al 12 reported that a high albumin/globulin ratio decreased risk for mixed cataract. We have examined the albumin/(total protein-albumin) ratio, which approximates the albumin/globulin ratio, for association with cataract.

Steroid use has been associated previously with cataracts in both humans and animals. ${ }^{13-16}$ Much earlier work has found a significant association between cataract and diabetes. $^{3-517}$ We analysed the effects of both steroid use and diabetes.

Clayton $e a^{7}{ }^{7}$ suggested that the differences in plasma constituents between patients and controls may differ for different age groups, hence the strict control for age in the present matched pair protocol. However, in order to investigate the effects of age on the differences in plasma constituents, as well as diabetic status and steroid use, an analysis of matched pairs was done in two groups, one less than 70 years of age and the other 70 or more years of age.

In the present (second) Edinburgh based study, we have measured the levels of 18 plasma constituents in a population of 1000 matched case-control pairs. Ten of these and the albumin/(total protein-albumin) ratio showed significant association with cataract.

\section{Patients and controls}

Of the 1000 patient-control pairs, 358 were male and 642 were female. Patients and controls were also matched on age (by half decade); the age distribution is displayed in Figure 1. 
Figure 1 Age distribution for matched patient-control pairs.

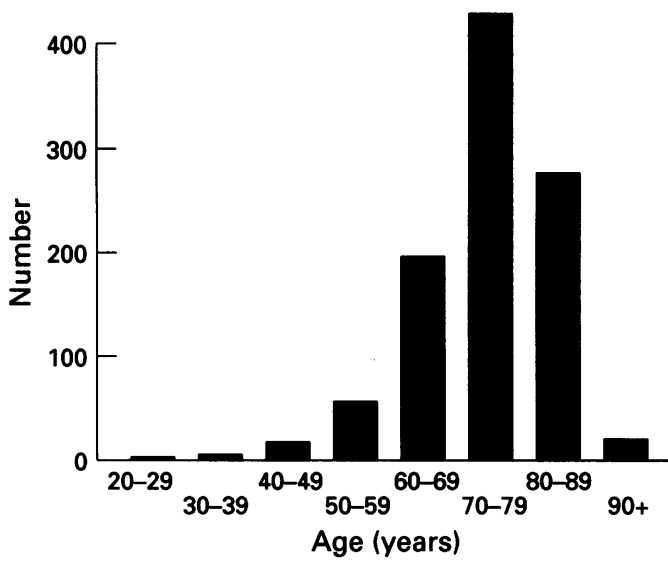

It is probable that patients who develop cataracts at early ages may experience a different pattern of cataract aetiology. The following analysis is therefore restricted to patients older than 49. Thus our data set consisted of 977 matched pairs. Of these patient-control pairs, 348 were male and 629 were female.

The plasma constituent data are missing for some individuals and thus are missing for the corresponding patient-control pairs. Insufficient specimens of plasma explain the deficits below 977 in Table 1; these deficits are larger in the multivariate analysis because the method of model selection demanded values for all of the constituents considered in all patients and controls.

\section{Methods \\ Nearly 2000 individuals form the basis for this report, comprising 977 patients on the waiting list for cataract operations at the Princess Alexandra Eye Pavilion, Royal Infirmary Edinburgh, and 977 controls. Briefly, an indi- vidual without cataract of the same sex and the same half decade of age as the patient was obtained from the list of the patient's general practitioner, thus ensuring that the patient and the control (who were unrelated either by con- sanguinity or marriage) resided in the same}

area of the city. Only one eye from each patient and control was included. In patients, the pupil of the eye to be operated was dilated with $1 \%$ tropicamide and the cataract assessed with a direct ophthalmoscope and a portable hand held slit-lamp microscope. The visual acuity of the patients' eyes was poor. To ensure the absence of significant cataract, controls had to have a visual acuity no worse than $6 / 9$ with correction in both eyes, neither operated; also there had to be no evidence of clinically significant cataract in the eye with the pupil dilated or its fellow.

Attempts were made initially to contact 1307 cataract patients and 2414 potential controls which suggests, not surprisingly, that patients were more willing to accept the invitation to join than were controls. One factor is that several other epidemiological studies had been or were being conducted in the Edinburgh area at this time, so that some patients and controls were unwilling to agree to yet another intrusion; only one practice in the whole area declined to participate, with that as the reason. One hundred and eighty eight potential controls were excluded because they had significant cataract. A higher proportion of excluded cataract patients $(86 / 307)$ were ill or in hospital than excluded controls (52/1414), but the death rates were the reverse (5/307 and $31 / 1414$, respectively). Among non-participants no reason could be ascertained in 141 patients and 918 potential controls because a relative or friend transmitted the refusal, or the non-participant merely left a telephone message. However, we have no reason to suspect that these imbalances have confounded our results.

Fasting blood samples were obtained by venepuncture from both patients and controls at an early morning domiciliary visit. All participants had been asked to ingest only water after the midnight before the appointed morning. No participants admitted non-compliance with the requirement. The analysis of plasma samples was undertaken in the Department

Table 1 Means, standard deviations, and univariate hypothesis testing results for 18 plasma constituents and the albumin/(total protein-albumin) ratio in patients and controls, including the estimated odds ratio (OR) and its corresponding $95 \%$ confidence interval (CI). $n$ Denotes the number of patientcontrol pairs with complete data for each plasma constituent.

\begin{tabular}{|c|c|c|c|c|c|c|c|c|c|}
\hline & \multirow[b]{2}{*}{ Normal range } & \multirow[b]{2}{*}{$n$} & \multicolumn{2}{|l|}{ Patients } & \multicolumn{2}{|l|}{ Controls } & \multirow[b]{2}{*}{ p Value } & \multirow[b]{2}{*}{ OR $(95 \%$ OR CI $)$} & \multirow{2}{*}{$\begin{array}{l}\text { For an } \\
\text { increase of }\end{array}$} \\
\hline & & & Mean & $S D$ & Mean & $S D$ & & & \\
\hline $\begin{array}{l}\text { Alanine aminotransferase } \\
\text { Albumin } \\
\text { Albumin/(total protein-albumin) } \\
\text { Alkaline phosphatase } \\
\text { Bilirubin } \\
\text { Calcium } \\
\text { Carbon dioxide, total } \\
\text { Cholesterol } \\
\text { Cortisol } \\
\text { Creatinine } \\
\text { Glucose (fasting) } \\
\gamma \text { glutamyl transpeptidase } \\
\text { Male } \\
\text { Female } \\
\text { Phosphate } \\
\text { Potassium } \\
\text { Protein, total } \\
\text { Sodium } \\
\text { Triglycerides } \\
\text { Urate } \\
\text { Male } \\
\text { Female } \\
\text { Urea }\end{array}$ & 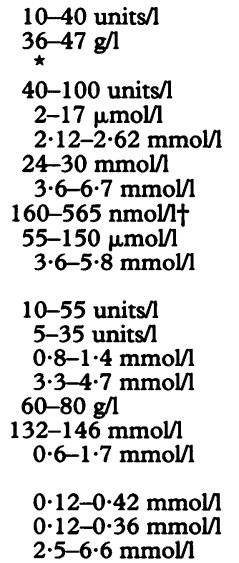 & $\begin{array}{l}878 \\
928 \\
925 \\
919 \\
925 \\
928 \\
927 \\
872 \\
858 \\
918 \\
920 \\
861\end{array}$ & $\begin{array}{c}21 \cdot 8 \\
43 \cdot 5 \\
1 \cdot 51 \\
103 \cdot 0 \\
10 \cdot 23 \\
2 \cdot 38 \\
26 \cdot 0 \\
6 \cdot 42 \\
416 \\
94 \cdot 3 \\
5 \cdot 64 \\
29 \cdot 8\end{array}$ & $\begin{array}{c}13 \cdot 7 \\
2 \cdot 9 \\
0 \cdot 24 \\
58 \cdot 8 \\
4 \cdot 22 \\
0 \cdot 10 \\
2 \cdot 9 \\
1 \cdot 34 \\
153 \\
23 \cdot 4 \\
2 \cdot 26 \\
40 \cdot 9\end{array}$ & $\begin{array}{c}21 \cdot 1 \\
43 \cdot 3 \\
1 \cdot 54 \\
93 \cdot 9 \\
9 \cdot 62 \\
2 \cdot 37 \\
26 \cdot 0 \\
6 \cdot 55 \\
380 \\
92 \cdot 7 \\
5 \cdot 23 \\
24 \cdot 8\end{array}$ & $\begin{array}{c}9 \cdot 6 \\
2 \cdot 6 \\
0 \cdot 23 \\
36 \cdot 1 \\
3 \cdot 73 \\
0 \cdot 10 \\
2 \cdot 7 \\
1 \cdot 30 \\
129 \\
23 \cdot 3 \\
1 \cdot 39 \\
26 \cdot 5\end{array}$ & $\begin{array}{r}0.19 \\
0.04 \\
0.01 \\
<<0.01 \\
<<0.01 \\
0.05 \\
0.99 \\
0.02 \\
<<0.01 \\
0.12 \\
<<0.01 \\
<0.01\end{array}$ & $\begin{array}{l}1.06(0.97,1.15) \\
1.04(1.00,1.07) \\
0.95(0.91,0.99) \\
1.27(1.12,1.43) \\
1.04(1.02,1.06) \\
1.10(1.00,1.20) \\
1.00(0.97,1.03) \\
0.91(0.84,0.99) \\
1.21(1.13,1.30) \\
1.03(0.99,1.0) \\
1.13(1.07,1.20) \\
1.26(1.08,1.49)\end{array}$ & $\begin{array}{l}10 \text { units } / 1 \\
1 \mathrm{~g} / 1 \\
0 \cdot 1 \\
50 \mathrm{units} / 1 \\
1 \mu \mathrm{mol} / 1 \\
0 \cdot 1 \mathrm{mmol} / 1 \\
1 \mathrm{mmol} / 1 \\
1 \mathrm{mmol} / 1 \\
100 \mathrm{nmol} / 1 \\
10 \mu \mathrm{mol} / 1 \\
1 \mathrm{mmol} / 1 \\
50 \mathrm{units} / 1\end{array}$ \\
\hline
\end{tabular}

*There is no information on the normal range of albumin/(total protein-albumin) ratio. $\nmid$ Normal range at 0800 hours. 
Table 2 Means and standard deviations of the albumin/(total protein-albumin) ratio and triglycerides by sex and of plasma glucose and triglycerides by age group in patients and controls. Significant results are reported for the tests of the hypotheses of no effect of sex or age stratum on the difference in plasma constituents, including the estimated odds ratio (OR) and its corresponding $95 \%$ confidence interval (CI)

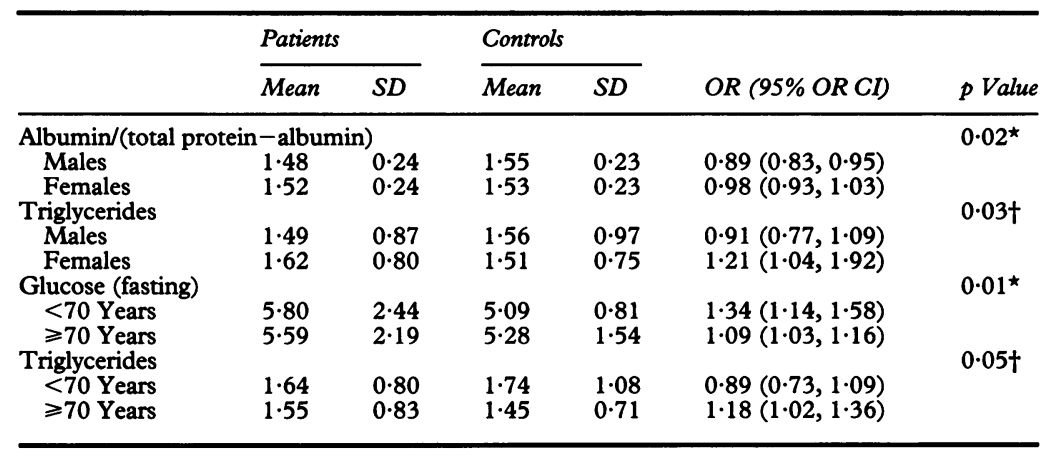

^Is a $1 \mathrm{df}$ test; tis a $2 \mathrm{df}$ test.

\section{Results}

\section{UNIVARIATE ANALYSES}

The cataract group showed significantly higher values of albumin, alkaline phosphatase, bilirubin, calcium, cortisol, glucose, $\gamma$ glutamyl transpeptidase, total protein, and sodium but significantly lower levels of cholesterol and the albumin/(total protein-albumin) ratio (Table 1).

\section{Effects of sex and age}

We have tested the hypothesis that the differences in plasma constituents between patients and controls do not depend on sex, by allowing the effect of each plasma constituent to differ for males and females. Only differences in the albumin/(total proteinalbumin) ratios and triglyceride levels depended significantly on sex (Table 2). Our earlier data ${ }^{7}$ suggested that the differences in plasma constituents between patients and controls may depend on age. We have tested for this possibility by allowing the effect of each plasma constituent to differ for the two age strata: less than 70 years and 70 or more years. Only plasma glucose and triglycerides were found to have significantly different odds ratios for the age strata (Table 2). No other differences in plasma constituent levels depended significantly on sex or age stratum.

Another way of examining the effect of age on the differences in plasma constituents is to regress the plasma constituent differences (patient minus control) on the age (in years) of the patient. The only significant effects of all the regressions of the differences between patients and controls were for alkaline phosphatase $(p=0.02)$, fasting glucose $(p=0.03)$, and triglycerides $(p=0.02)$. The results indicate that there is a steadily decreasing difference in glucose, by $0.022 \mathrm{mmol} / \mathrm{l}(\mathrm{SE}=0.010)$ for each additional year of age; that after the age of 59 years, there is a steadily increasing difference in alkaline phosphatase, by 0.59 units $/ 1(S E=0.26)$ for each additional year of age; and that there is a steadily increasing difference in triglycerides, by $0.011 \mathrm{mmol} / \mathrm{l}$ $(\mathrm{SE}=0.005)$ for each additional year of age from an estimated difference of $-0.23 \mathrm{mmol} / \mathrm{l}$ at age 50 , to $0 \mathrm{mmol} / \mathrm{l}$ at age 70 , and 0.22 $\mathrm{mmol} / \mathrm{l}$ at age 90 . model selection, it is necessary for patient-control pairs analysed to have complete data for the variables under consideration.

Table 3 The multivariate logistic regression model $(n=724)$ obtained allowing effects of 10 plasma constituents, the albumin/(total protein-albumin) ratio, diabetes, and steroid use. Significant variables are listed with the $p$ value for the null hypothesis of no effect of each variable, the estimated odds ratio (OR), and its corresponding $95 \%$ confidence interval (CI)

\begin{tabular}{|c|c|c|c|}
\hline & p Value & OR (95\% OR CI) & $\begin{array}{l}\text { For an } \\
\text { increase of }\end{array}$ \\
\hline $\begin{array}{l}\text { Alkaline } \\
\text { phosphatase } \\
\text { Bilirubin } \\
\text { Cortisol } \\
\text { Protein, total } \\
\text { Diabetic } \\
\text { Steroids }\end{array}$ & $\begin{aligned} & 0.01 \\
&<<0.01 \\
&<<0.01 \\
&<<0.01 \\
&<<<0.01 \\
&<<0.01\end{aligned}$ & $\begin{array}{l}1.04(1.01,1.07) \\
1.05(1.02,1.08) \\
1.19(1.09,1.30) \\
1.05(1.02,1.07) \\
2.90(1.72,4.88) \\
2.53(1.52,4.22)\end{array}$ & $\begin{array}{c}10 \text { units } / \\
1 \mu \mathrm{mo} / / \\
100 \mathrm{nmo} / 1 \\
1 \mathrm{~g} / 1\end{array}$ \\
\hline
\end{tabular}

No other variables were significant in the multivariate analysis.

\section{Effects of diabetes and steroid use}

For the complete data $(n=724)$, diabetic status analysed univariately was highly significant $(p<<0.01)$ with an odds ratio of 3.25 and a $95 \%$ confidence interval of 1.97 to $5 \cdot 37$. The 
Table 4 The multivariate logistic regression model $(n=637)$ for non-diabetics obtained allowing effects of 10 plasma constituents, the albumin/(total protein-albumin) ratio, and steroid use. Significant variables are listed with the $p$ value for the null hypothesis of no effect of each variable, the estimated odds ratio (OR), and its corresponding $95 \%$ confidence interval (CI)

\begin{tabular}{lrrr}
\hline & $p$ Value & OR $(95 \%$ OR CI) & $\begin{array}{l}\text { For an } \\
\text { increase of }\end{array}$ \\
\hline Alkaline & & & \\
phosphatase & 0.02 & $1.03(1.01,1.06)$ & $10 \mathrm{units} /$ \\
Bilirubin & 0.01 & $1.04(1.01,1.07)$ & $1 \mu \mathrm{mol} / \mathrm{h}$ \\
Cholesterol & 0.05 & $0.90(0.82,1.00)$ & $1 \mathrm{mmol} /$ \\
Cortisol & $<<0.01$ & $1.20(1.10,1.31)$ & $100 \mathrm{nmol} /$ \\
Protein, total & $<<0.01$ & $1.06(1.03,1.09)$ & $1 \mathrm{~g} / 1$ \\
Steroids & $<<0.01$ & $2.70(1.58,4.61)$ &
\end{tabular}

No other variables were significant in the multivariate analysis.

odds ratio did not depend significantly on sex or age stratum. The regression of differences in diabetic status on age of the patient was not significant.

For the complete data $(n=724)$, steroid use analysed univariately was highly significant $(\mathrm{p}<<0.01)$ with an odds ratio of 2.21 and a $95 \%$ confidence interval of 1.36 to 3.58 . The odds ratio for steroid use did not vary significantly for sex or age strata. The regression of differences in steroid use on age of the patient was not significant.

\section{MULTTVARIATE ANALYSES}

Table 3 presents the multivariate model obtained with a step up selection procedure incorporating the variables found to be significant in the univariate analyses.

\section{Analysis of non-diabetics}

Of the 724 matched patient-control pairs, 637 were pairs of non-diabetics (224 male and 413 female). Table 4 presents the multivariate model obtained for the non-diabetic pairs using a step up selection procedure incorporating the variables found to be significant in the univariate analyses. We found no significant association for glucose when the data were analysed univariately $(p=0.59)$, and plasma glucose was not selected for inclusion in the multivariate model for non-diabetics.

\section{Analysis of non-steroid users}

Of the 724 matched patient-control pairs, 645 were pairs of non-steroid users (234 male and 411 female). Among non-steroid users there remained a significant association between

Table 5 The multivariate logistic regression model $(n=645)$ for non-steroid users obtained allowing effects of 10 plasma constituents, the albumin/(total protein-albumin) ratio, and diabetes. Significant variables are listed with the $p$ value for the null hypothesis of no effect of each variable, the estimated odds ratio (OR), and its corresponding $95 \%$ confidence interval (CI)

\begin{tabular}{|c|c|c|c|}
\hline & p Value & OR (95\% OR CI) & For an increase of \\
\hline $\begin{array}{l}\text { Alkaline phosphatase } \\
\text { Bilirubin } \\
\text { Cortisol } \\
\text { Glucose (fasting) }<70 \text { years } \\
\text { Glucose (fasting) } \geqslant 70 \text { years } \\
\text { Protein, total } \\
\text { Diabetic }\end{array}$ & $\begin{array}{r}0.01 \\
<<0.01 \\
<<0.01 \\
0.04 \\
0.86 \\
<<0.01 \\
0.01\end{array}$ & $\begin{array}{l}1.04(1.01,1.07) \\
1.05(1.02,1.08) \\
1.23(1.11,1.34) \\
1.29(1.01,1.63) \\
0.99(0.91,1.08) \\
1.05(1.02,1.08) \\
2.36(1.20,4.63)\end{array}$ & $\begin{array}{l}10 \mathrm{units} / 1 \\
1 \mathrm{\mu mol} / \\
100 \mathrm{nmol} / 1 \\
1 \mathrm{mmol} / / \\
1 \mathrm{mmol} / \\
1 \mathrm{~g} / 1\end{array}$ \\
\hline
\end{tabular}

No other variables were significant in the multivariate analysis. cataract and cortisol, with an odds ratio of $1 \cdot 28$ for an increase of $100 \mathrm{nmol} / \mathrm{l}$ of cortisol $(p<<0.01)$. Table 5 presents the multivariate model obtained for the non-steroid users using a step up selection procedure incorporating the variables found to be significant in the univariate analyses.

\section{Discussion and conclusions}

SPECIFIC

The present study was very stringently case-controlled and used large numbers of patient-control pairs, so that we are confident of our findings. Many of the present results corroborate our earlier observations on a different group of patients from a population in the same geographic area.

It is important to note a very highly significant rise in three plasma constituents: alkaline phosphatase, bilirubin, and $\gamma$ glutamyl transpeptidase (Table 1). The combination of these findings, together with the lack of a significant increase in alanine aminotransferase, would be consistent with an association between mild intrahepatic cholestasis and cataract. Whether this reflects the presence of subclinical liver dysfunction or the cholestatic effects of therapeutic drugs in the patient group cannot be determined from the present data. This is consistent with our previous findings of significantly raised bilirubin levels. ${ }^{67}$ However, alkaline phosphatase was not significantly raised in the cataract patients previously. $^{\text {? }}$

Therapeutic steroid taking was more common in the cataract group than in the controls (Tables 3 and 4). Patients showed a higher level of endogenous basal plasma cortisol levels than the controls, irrespective of steroid use and diabetic status (Tables 1, 3, 4, and 5), indicating that the significance of cortisol is not explained by steroid use or diabetes. Raised circulatory glucocorticoid levels probably have a directly deleterious effect on lens metabolism, but the slight rise in basal plasma steroid may also act indirectly for example, by an association with raised blood pressure, a known risk factor. ${ }^{1410}$

Cholesterol levels were significantly lower in the cataract group than in the controls, consistent with our previous study, ${ }^{4-7}$ possibly due to diet or an abnormality in liver function. The lower cholesterol might imply a defect in metabolism of cell membrane important in cataractogenesis. Consistently, in a previous study ${ }^{5}$ corneal arcus, which is associated with hypercholesterolaemia and coronary artery disease, ${ }^{18}$ was commoner and more marked in the control group than in the cataract group. Triglyceride levels were not significantly different, either in the present or in the previous study. 45

In contrast with previous findings, ${ }^{15-7}$ fasting glucose levels did not differ significantly between the two groups in a multivariate model controlling for diabetes (Table 3) or when known diabetics were excluded (Table 4). A borderline significant increase in glucose 
levels among patients was, however, observed in non-steroid users less than 70 years of age (Table 5). Because of the multiplicity of significance tests performed, that result may be a chance finding, but it is consistent with an earlier study ${ }^{17}$ which found no increased risk of cataract for diabetics compared with non-diabetics after the age of 65 years.

Sodium levels were significantly raised in the cataract patients in the present study, in contrast with the earlier study. ${ }^{47}$ An association between raised sodium levels and cataract may also be mediated through the effect of salt intake on hypertension. ${ }^{19}$

Although urea in the cataract group was significantly raised in our previous study, 457 the small rise was not significant in the present study (Table 1). Similarly, there was no significant difference in the levels of urate or creatinine, indicating no difference in renal function.

The levels of potassium, phosphate and $\gamma$ glutamyl transpeptidase all gave inconsistent results between the earlier ${ }^{47}$ and the present Edinburgh based studies, but the latter used a more stringent design.

The mean total carbon dioxide levels were virtually identical in the present cataract and control groups, implying that there was no intergroup difference in the delay between sample collection and analysis (some diffusion of carbon dioxide occurs with time). However, in our previous study 57 the mean level was significantly lower in the patients. This discrepancy is unlikely to reflect the fact that in the previous study the controls were ambulatory, but the patients were resting, while in the present study all samples were taken under identical conditions, but that explanation probably does account for other discrepancies. In our previous study, albumin, calcium, and total protein were significantly lower in the cataract group ${ }^{4-7}$ whereas in the present study these constituents were significantly higher. We regard the results in the present study as the more valid, because the exercise in the previous control group may well have reduced their albumin, calcium, and total protein levels.

The albumin/(total protein-albumin) ratio in the present study was significantly lower in the cataract group, which is consistent with earlier findings. ${ }^{12}$ The relative increase in the globulin fraction in the cataract group could be associated with infection which was found to be significantly associated with cataract in the previous study. ${ }^{720}$

GENERAL

The pair-matching on sex and age (by half decade) has reduced the chance of bias. The level of some serum constituents varies with age $^{21}$; however, when a value in any patient or control was missing, the matched pair was eliminated, so that there is no difference in age between the two groups to confound our observations. Furthermore, venepuncture was performed with subjects fasting at an early morning visit to the homes of all patients and controls. The close similarity of total plasma carbon dioxide levels in patients and controls validates the claim for standardisation of specimen collection in the two groups.

All surveys such as the present one entail the possibility that mere chance may be responsible for a particular significant difference, a proposition fundamental to all statistical analyses. The greater the number and diversity of quantifiable properties compared between groups, the greater the likelihood that one or more will differ significantly merely by chance. There are many statistical methods available to correct the $p$ values for the number of tests performed $^{22} 23$; however, we have reported unadjusted $\mathrm{p}$ values in order to allow the reader access to the raw test results independent of a specific correction method. Agreement with a previous finding of a significant difference increases confidence in a conclusion, but an unexpected finding at the borderline of significance may well be attributed to chance.

Almost all the mean values estimated in both groups are within the generally accepted normal reference range, which is 2 standard deviations from the mean of a large parent population. The only exception is the mean value of alkaline phosphatase at 103 units/1 (Table 1) in the cataract group which is slightly higher than the upper end of the normal reference range; however, the control mean level is also at the high end of the normal range, reflecting the higher levels found in the elderly. The distribution of patient control differences was examined for each plasma constituent and found to be symmetric, indicating that the significant differences between patients and controls were not due to a small group of very abnormal individuals but rather to a shift of the whole cataract group compared with the control group. Thus, even though the mean plasma constituent levels of both patients and controls are within the normal range, the statistically significant differences are important in relation to cataractogenesis, especially as we have provided evidence that risk factors are additive. ${ }^{7}$

Although we have focused in this paper on correlations between human plasma constituents and cataract, potential confounders exist, including documented risk factors such as smoking, ${ }^{24-29}$ alcohol consumption, ${ }^{30-37}$ and diet (in particular antioxidant status). ${ }^{38-44}$ (For a review of these and other risk factors for cataract, see West and Valmadrid ${ }^{45}$.) Our present study contributes new information to the complex aetiology of cataract.

We are grateful to The Gift of Thomas Pocklington who have given us encouragement and generous financial support throughout. We also thank the Royal National Institute for the Blind for an initial grant. We are grateful to the following who performed ophthalmic examinations in the homes of patients and controls: Dr $\mathrm{Z}$ Butt, Dr J Crispin, Dr R Dunlop, Dr A Fairley, Dr T Jordan, Dr S Mackenzie, Dr B Ritchie, and Dr M Rogers; and to the following who were responsible for the $\mathrm{Dr}$ Rogers; and to the following who were responsible for the completion of the questionnaires and venepunctures: Ms K Cumming, Ms I Hall, Ms T Law, and Ms A Turnbull. The cooperation of the general practitioners in the Edinburgh area and their patients is greatly appreciated, as is the agreement by the consultant surgeons at the Princess Alexandra Eye Pavilion to allow access to their patients. We are also grateful to Ms P Graham, the secretary responsible for administration.

1 Kahn HA, Leibowitz HM, Ganley JP, Kini MM, Colton T, Nickerson RS, et al. The Framingham Eye Study. II. Association of ophthalmic pathology with single variables 
previously measured in the Framingham Heart Study. Am f Epidemiol 1977; 106: 33-41.

2 Harding J, Egerton M, Van Heyningen R, Harding RS Diabetes, glaucoma, sex, and cataract: analysis of combined data from two case-control studies. Brf Ophthalmo 1993; 77: 2-6.

3 Bartholomew RS, Clayton RM, Cuthbert J, Duffy J, Phillips CI, Reid JM, et al. Analysis of individual cataract patients and their lenses: preliminary observations on a population basis. In: Regnault F, Hockwin O, Courtois Y, eds. Ageing basis. In: Regnault $\mathrm{F}$, Hockwin $\mathrm{O}$, Courtois Y, eds. Ageing
of the lens. Amsterdam: Elsevier/North-Holland of the lens. Amsterdam:

4 Phillips CI, Bartholomew RS, Clayton R, Duffy J, Seth J, Reid JM, et al. Cataracts: a search for associations or causative factors. In: Regnault F, ed. Symposium on the lens. Princeton, NJ: Excerpta Medica, 1980: 19-25.

5 Clayton RM, Cuthbert J, Phillips CI, Bartholomew RS, Stokoe NL, Ffytche T, et al. Analysis of individua Eye Res 1980; 31: 553-6.

6 Clayton RM, Cuthbert J. Duffy J, Seth J, Phillips CI, Bartholonew RS, et al. Some risk factors associated with cataract in SE Scotland: a pilot study Trans Ophthalmol Soc UK 1982; 102: 331-6.

7 Clayton RM, Cuthbert J, Seth J, Phillips CI, Bartholomew RS, Reid JM. Epidemiological and other studies in the assessment of factors contributing to cataractogenesis. CIBA Foundation Symposium 1984; 106: 25-40.

8 Cuthbert J, Clayton RM, Phillips CI, Seth J. Diuretic drugs as risk factors in cataractogenesis. Metabolic, Pediatric and Systemic Ophthalmology 1987; 10: 48-54.

9 Miglior S, Bergamini F, Migliavacca L, Marighi P, Orzalesi N. Metabolic and social risk factors in a cataractous population. A case-control study. Dev Ophthalmol 1989; 17: $158-64$.

10 Mohan M, Sperduto RD, Angra SK, Milton RC, Mathur RL, Underwood BA, et al. India-US case-control study of RL, Underwood BA, et al. India-US case-control study of 1 Italian-American Study Group. Risk factors for age-related cortical, nuclear, and posterior subcapsular cataracts. $A m$ f Epidemiol 1991; 133: 541-53.

12 Schoenfeld ER, Leske MC, Wu S-Y. Recent epidemiologic studies on nutrition and cataract in India, Italy and the United States. F Am Coll Nutr 1993; 12: 521-6.

13 Fryer JP, Granger DK, Leventhal JR, Gillingham $K$, Najarian JS, Matas AJ. Steroid-related complications in the cyclosporine era. Clin Transplant 1994; 8: 224-9.

14 Tichelli A, Gratwohl A, Egger T, Roth J, Prunte A, Nissen $\mathrm{C}$, et al. Cataract formation after bone-marrow transC, et al. Cataract formation after bone-marro

15 Butcher JM, Austin M, McGalliard J, Bourke RD. Lesson of the week - bilateral cataracts and glaucoma induced by long-term use of steroid eye drops. BMF 1994; 309: 43.

16 Nagata $M$, Hikida $M$, Mibu $H$, Muto N. Yamamoto I Effect of ascorbic-acid 2-o-alpha-glucoside on hydrocortisone-induced cataract formation in developing chickembryos. 2. Influence on glutathione and lipid peroxide contents in the lens. FOcular Pharmacol 1994; 10: 537-42.

17 Ederer F, Hiller R, Taylor HR. Senile lens changes and diabetes in two population studies. Am $\mathcal{f}$ Ophthalmol 1981; 91: 381-95.

18 Rosenman RH, Brand RJ, Sholtz RI, Jenkins CD. Relation of corneal arcus to cardiovascular risk factors and the inciof corneal arcus to cardiovascular risk factors and the incidence of

19 Camm AJ. Cardiovascular disease. In: Kumar P, Clark M, eds. Clinical medicine: a textbook for medical students and doctors. 3rd ed. London: Bailliere Tindall, 1994: 521-630.

20 Harding JJ, Rixon KC. Is diarhoea a major cause of cataract in some tropical countries? Metabolic, Pediatric and Systemic Ophthalmology 1981; 5: 161-6.

21 Hodkinson HM. Biochemical diagnosis in the elderly. London: Chapman \& Hall, 1977.
22 Rom DM, Connell L. A generalized family of multiple test procedures. Communications in Statistics - Theory and Methods 1994; 23: 3171-87.

23 Hommel G, Bernhard G. A rapid algorithm and a computer-program for multiple test procedures using logical-structures of hypotheses. Computer Methods and Programs in Biomedicine 1994; 43: 213-6.

24 Flaye DE, Sullivan KN, Cullinan TR, Silver JH, Whitelocke RAF. Cataracts and cigarette smoking: the City Eye Study. Eye 1989; 3: 379-84.

25 West S, Munoz B, Emmett EA, Taylor HR. Cigarette smoking and risk of nuclear cataracts. Arch Ophthalmol 1989; 107: 1166-9.

26 Christen WG, Manson JE, Seddon JM, Glynn RJ, Buring $\mathrm{JE}$, Rosner B, et al. A prospective study of cigarette smoking and risk of cataract in men. $\mathcal{F}$ Am Med Assoc 1992; 268: 989-93.

27 West S, Munoz B, Vitale S, Schein OD, Maguire $M$, Bressler N. Watermen Study II: Smoking and nuclear opacities. Invest Ophthalmol Vis Sci 1992; 33: 1097.

28 Hankinson SE, Willett WC, Colditz GA, Seddon JM, Rosner B, Speizer FE, et al. A prospective study of cigarette smoking and risk of cataract surgery in women. ЭAM $A$ 1992; 268: 994-8.

29 Klein BEK, Klein R, Linton KLP, Franke T. Cigarette smoking and lens opacities: the Beaver Dam Eye Study. Am $\mathcal{F}$ Prevent Med 1993; 9: 27-30.

30 Sabiston DW. Cataracts, Dupuytren's contracture, and alcohol addiction. Am f Ophthalmol 1973; 76: 1005-7.

31 Harding J, Van Heyningen R. Drugs, including alcohol, that act as risk factors for cataract, and possible protection against cataract by aspirin-like analgesics and cyclopenthiazide. Br $\mathcal{O}$ Ophthalmol 1988; 72: 809-14.

32 Drews RC. Alcohol and cataract. Arch Ophthalmol 1993; 111: 1312.

33 Munoz B, Tajchman U, Bochow T, West S. Alcohol use and risk of posterior subcapsular opacities. Arch Ophthalmol 1993; 111: 110-2.

34 Munoz B, West S, Vitale S, Schein OD, Maguire M, Taylor HR. Alcohol use and cataract in a cohort of Chesapeake Bay watermen. Invest Ophthalmol Vis Sci 1993; 34: 1066.

35 Ritter LI, Klein BEK, Klein R, Mares-Perlman JA. Alcohol use and lens opacities in the Beaver Dam Eye Study. Arch Ophthalmol 1993; 111: 113-7.

36 Manson JE, Christen WG, Seddon JM, Glynn RJ, Hennekens $\mathrm{CH}$. A prospective study of alcohol consumption and risk of cataract. Am F Prevent Med 1994; 10: tion and 61 .

37 Phillips CI, Clayton RM, Cuthbert J, Oian W, Donnelly CA, Prescott. RJ. Human cataract risk factors: significance of abstention from, and high consumption of, ethanol (U-curve) and non-significance of smoking. (Submitted for publication.)

38 Bunce GE. Nutrition and cataract. Nutr Rev 1979; 37: $337-43$.

39 Jacques PF, Chylack LT, McGandy RB, Hartz SC. Antioxidant status in persons with and without senile cataract. Arch Ophthalmol 1988; 106: 337-40.

40 Jacques PF, Hartz SC, Chylack LT, McGandy RB, Sadowski JA. Nutritional status in persons with and without senile cataract: blood vitamin and mineral levels. $\mathrm{Am}$ f Clin Nutr 1988; 48: 152-8.

41 Bunce GE, Kinoshita J, Horwitz JH. Nutritional factors in cataract. Annu Rev Nutr 1990; 10: 233-54.

42 Taylor A. Role of nutrients in delaying cataracts. Ann NY Acad Sci 1992; 669: 111-24.

43 Taylor A. Cataract - relationships between nutrition and oxidation. F Am Coll Nutr 1993; 12: 138-46

44 Sarma U, Brunner E, Evans J, Wormald R. Nutrition and the epidemiology of cataract and age-related maculopathy. Eur f Clin Nutr 1994; 48: 1-8.

45 West, SK, Valmadrid CT. Epidemiology of risk factors for age-related cataract. Surv Ophthalmol 1995; 39: 323-34. 